\title{
EFFECTS OF THIOSULFONATES ON THE LIPID COMPOSITION OF RAT TISSUES
}

\author{
A. Z. PYLYPETS ${ }^{1,2}$, R. Ya. ISKRA 2 , V. V. HAVRYLIAK ${ }^{1,2}$, \\ A. V. NAKONECHNA ${ }^{1}$, V. P. NOVIKOV ${ }^{1}$, V. I. LUBENETS ${ }^{1 *}$ \\ ${ }^{1}$ Lviv Polytechnic National University, Ukraine; \\ ${ }^{2}$ Institute of Animal Biology, NAAS of Ukraine, Lviv; \\ e-mail:vlubenets@gmail.com
}

Thiosulfonates are synthetic analogs of organic sulfur-containing compounds isolated from plants. Recent studies have shown that these substances lowering cholesterol content in the body, are effective against hyperlipidemia. Therefore, the aim of our investigation was to study the effect of synthesized thiosulfonates on the content of lipids and their spectrum in rats blood, liver and kidney. The amount of total lipids and their fractional profile was determined by thin-layer chromatography. The administration of methyl-, ethyl-, and allylthiosulfonates at a dose of $300 \mathrm{mg} / \mathrm{kg}$ of body weight did not cause significant changes in the content of total lipids and phospholipids, but led to the redistribution of their classes in the examined tissues. The content of triacylglycerols in the blood plasma under the action of ethyl- and allylthiosulfonates was decreased by 29.14 and $23.19 \%(P<0.05-0.01)$, respectively, whereas the injection with methyl- and ethylthiosulfonates was accompanied by a significant decrease in mono-, di-, triglycerides and free fatty acids in the liver compared to control. The most significant changes in the lipid profile of kidney tissue were detected under the action of methylthiosulfonate.

Key word s: thiosulfonates, blood, liver, kidney, total lipids, phospholipids, fractional composition.

$\mathrm{N}$ owadays the urgent problem of the modern pharmaceutical chemistry is the search for biologically active substances with a wide range of biological effects, which can become the basis for the development of new biocides and medicines. These substances include organic sulfur compounds, isolated from the garlic, onions, cauliflower, broccoli etc. [1] and their structural ana$\operatorname{logs}-$ synthetic thiosulfonates [2]. The advantages of synthetic thiosulfonates over natural compounds are their stability, as well as low toxicity for animals [2]. Synthetic thiosulfonates are characterized by a wide range of antibacterial and antifungal activities $[3,4]$. Propyl-propane thiosulfonate, isolated from garlic, affects enteropathogens, such as subspecies Salmonella, Campylobacter jejuni, Clostridium perfrigens and Escherichia coli. Dietary supplementation of propyl-propane thiosulfonate could modulate the composition of the broiler's intestinal microbiota and increase feed digestibility [5]. It is believed that the antimicrobial activity of thiosulfonates is closely related to their ability to block the normal metabolism of microorganisms through sulfenylation of thiol groups of their enzymes [6].

Propyl-propane thiosulfonate is effective against coccidia [7], it can be added to animal feed as an alternative to growth promoters [8], as well as reduces methane emissions in ruminants [9].

It has been shown that sodium salts of S-alkyl thiosulfonates and S-alkyl sulfonates can reduce inflammation of the paws in rats caused by carrageenan. The most effective anti-inflammatory properties were detected for partially screened phenol with the thiosulfonate group (TS-13). The authors suggest that such anti-inflammatory effects of these synthetic compounds are associated with their effect on redoxsensitive transcription factors and the expression of appropriate proinflammatory genes [10].

Existing data indicate that organic sulfur compounds manifest cytotoxic effects on cancer cells, in-

(C) 2017 Pylypets A. Z. et al. This is an open-access article distributed under the terms of the Creative Commons Attribution License, which permits unrestricted use, distribution, and reproduction in any medium, provided the original author and source are credited. 
hibiting their growth through the arrest of the $\mathrm{G}_{2} / \mathrm{M}$ cell cycle and inducing apoptosis both in vitro and in vivo [11]. Moreover, these compounds can induce the formation of active forms of oxygen caused by a cascade of cytotoxic effects in promyeloleukemic [12], glioblastoma [13] neuroblastoma [14], lymphoma, breast cancer and esophagus cell lines [15, 16].

Our previous studies have shown that the synthesized esters of 4-amino- and 4-acylbenzenethiosulfoacids have a powerful antimicrobial effect, which is closely related not only to their ability to block the $\mathrm{SH}$ - and $\mathrm{NH}_{2}$-groups of proteins but also to manifest properties, similar to sulfonamides $[4,17]$.

Thus, nowadays there is enough information about the antimicrobial, antifungal and cytotoxic properties of thiosulfonates, but little is known about the effects of these compounds on metabolic processes in the animal organism. Taking into account that organic sulfur compounds may affect lipid metabolism, the aim of current study was to analyze the effect of the administration of synthesized thiosulfonates on the lipid profile of blood, liver and kidney tissues in rats.

\section{Materials and Methods}

Synthesis of thiosulfonates. In current work, we used allyl-4-aminobenzenethiosulfonate (ATC), ethyl-4-aminobenzenethiosulfonate (ETS) and methyl-4-aminobenzenethiosulfonate (MTS). All compounds were synthesized in Department of technology of biologically active compounds, pharmacy and biotechnology (Lviv Polytechnic National University), in accordance with the protocol described in detail in $[2,4]$.

Animals. For experiments, male rats with body weight 190-210 g were used. All experimental procedures were performed in accordance with the requirements of European Convention for the Protection of Vertebrate Animals Used for Experimental and Other Scientific Purposes (Strasbourg, 1986) and the National general ethical principles of experiments on animals (Ukraine, 2001). Animals were housed under controlled laboratory conditions. The rats were fed a standard pellet feed and filtered drinking water ad libitum.

Wistar rats were randomly divided into 4 groups (control $\mathrm{K}$ and three experimental: A, E, $\mathrm{M})$ each containing 5 animals.

For the administration to animals, thiosulfonates were dissolved in sterile oil (trademark “Oleyna", DSTU ISO 14024, Ukraine). The solution was freshly prepared and administered intraperitoneally at a dose of $300 \mathrm{mg} / \mathrm{kg}$ of body weight once a day: group A - allylthiosulfonate (ATS), group E ethylthiosulfonate (ETC), group M - methylthiosulfonate (MTS). Animals of the control group were injected an appropriate dose of sterile oil.

After three days of the experiment, rats were sacrificed under ether anesthesia. The samples of blood, liver and kidney were collected. All procedures on tissues were carried out at $4{ }^{\circ} \mathrm{C}$.

Extraction of lipids. Blood plasma and tissue homogenates were extracted with chloroform-methanol mixture $(2: 1, \mathrm{v} / \mathrm{v})$ by the Folch method [18]. A solution of $\mathrm{KCl}(0.74 \mathrm{M})$ was added to each sample of the lipid extract. After $24 \mathrm{~h}$ the upper phase containing hydrophobic peptides was removed by a water pump, and a lower phase, which contained the lipids, was filtered. The lipid extracts were evaporated to dryness and then weighed on an analytical balance.

Separation of total lipids. The separation of lipids into classes was performed using thin-layer chromatography on silica gel plates (silica gel L 5/40 $\mu$, LSL 5/40 $\mu$, Chemapol, Czech Republic). Hexane-diethyl ether-acetic acid (70:30:1, v/v/v) was used as an eluent system [19]. Classes of lipids were revealed in vapors of crystalline iodine. Identification of individual lipids was carried out with Rf-values. Quantitative analysis of the lipid classes was performed using the TotalLab TL120 software (Nonlinear Dynamics Limited, UK) and expressed as a percentage of the total pool.

Statistical analysis. Statistical evaluation of the results was conducted using the arithmetic mean and standard error $(M \pm m)$ and the adequate interval for assessing the degree of probability $(P)$ using Student's criterion $(t)$. Differences were statistically significant at $P<0.05$. All calculations were performed using Microsoft Excel software.

\section{Results and Discussion}

It is well known that organic sulfur-containing compounds of garlic, onions, etc., are effective against hyperlipidemia, lowering the lipid content in blood [20]. Our results showed that administration of thiosulfonates had no effect on the total lipids in blood plasma of rats (Fig.). We also found the tendency to decrease its level in animals of experimental group A, which were injected with allylthiosulfonate.

Similar changes of total lipid content were observed in the liver of rats. It has been revealed that the content of total lipids decreased by $19.3 \%$ 
a

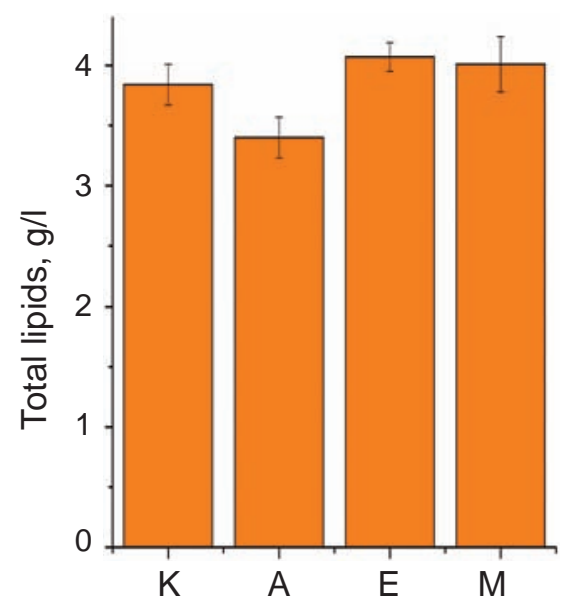

$\boldsymbol{b}$

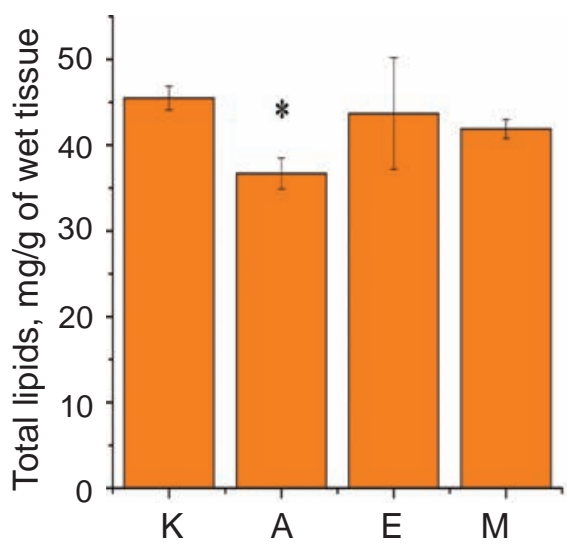

c

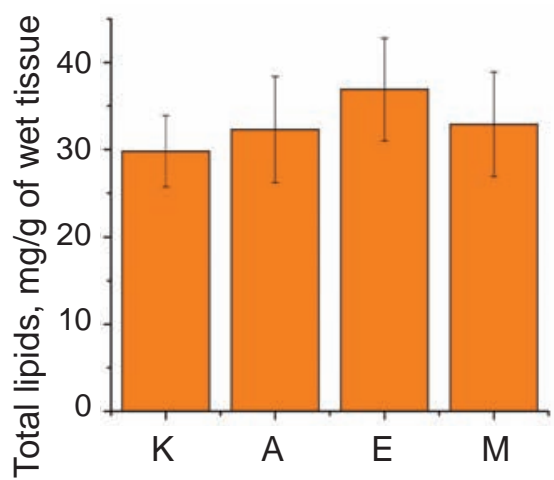

The content of total lipids in: $\boldsymbol{a}$ - blood plasma; $\boldsymbol{b}-$ liver; $\boldsymbol{c}$ - kidney. $K$ - control, $A$ - allylthiosulfonate (ATS), group E - ethylthiosulfonate (ETC), group $M$ - methylthiosulfonate (MTS). *, **, *** - the differences are statistically significant compared to the control group $(P<0.05-0.001)$

$(P<0.01)$ in rats injected with allylthiosulfonate. This is explained an adaptive reorganization of metabolic processes in the animal organism [21]. At the same time, no significant differences were observed between total lipids content in the kidney of all experimental groups, compared with the control animals.

As can be seen from the results of Table 1, the largest part of total lipids in blood plasma is the fraction of phospholipids, but there was no detectable change of its content between the control and the experimental groups. A significant decrease of triglycerides to 23.19 and $29.14 \%(P<0.05-0.01)$ from the control was detected in rats injected with allyl- and ethylthiosulfonates respectively. It should be noted that the literature data report that allicin and its derivatives can decrease the content of cholesterol and triglycerides in blood serum, reduce platelet aggregation and the risk of atherosclerotic plaque formation [22].

In the present study, the same lipid components in rat's liver of all groups (Table 2) were observed but the quantitative content of individual fractions was significantly different. It should be noted that fractions of mono-, diglycerides and free fatty acids decreased significantly in animals of all experimental groups. However, the most significant changes in the lipid profile of liver tissue were observed in the group of rats, injected with methyl- and ethylthiosulfonates. In these animals, the triglycerides content in the liver tissue reduced by $34.0 \%$ and $28.6 \%$, respectively. On the one hand, these data may indicate the mobilization of tissue lipids into circulation and on the other hand - on the inhibition of activities of enzymes involved in the synthesis of lipids [23].

The largest content of phospholipids was observed in the liver of animals of the experimental group M. It is likely that a higher content of this fraction of lipids in the liver may indicate their use in adaptive rearrangements of the structural components of hepatocytes [24].

Our results have shown that the lipid profile of kidney is characterized by the significant decrease in triglycerides in animals of the group E and $\mathrm{M}$ (Table 3).

The intraperitoneal administration of methylthiosulfonate is also accompanied by an increase in free cholesterol and unesterified fatty acids. It is known that free cholesterol and phospholipids affect the functional activity of cell membranes. Therefore, the high level of free cholesterol can cause changes in membrane fluidity and its permeability [25].

The lowest content of esterified cholesterol was found in animals injected with allylthiosulfonate that may indicate the changes in the activity of enzymes involved in the cellular homeostasis of cholesterol. 
Ta b le 1. Fractional composition of total lipids in blood plasma, $\%, M \pm m, n=5$

\begin{tabular}{|c|c|c|c|c|}
\hline \multirow{2}{*}{ Class of lipids } & \multirow{2}{*}{ Control group } & \multicolumn{3}{|c|}{ Experimental group } \\
\hline & & $\mathrm{A}$ & $\mathrm{E}$ & M \\
\hline Phospholipids & $47.15 \pm 10.51$ & $48.49 \pm 1.30$ & $47.58 \pm 9.49$ & $30.95 \pm 4.79$ \\
\hline Nonesterified cholesterol & $14.99 \pm 1.20$ & $15.32 \pm 2.93$ & $11.81 \pm 2.52$ & $13.70 \pm 2.25$ \\
\hline Mono- and diglycerides & $11.00 \pm 3.30$ & $11.19 \pm 2.57$ & $12.82 \pm 3.38$ & $14.03 \pm 2.71$ \\
\hline Free fatty acids & $4.21 \pm 0.70$ & $5.85 \pm 0.97$ & $10.91 \pm 3.31$ & $7.61 \pm 2.01$ \\
\hline Triglycerides & $13.28 \pm 0.60$ & $10.20 \pm 0.14^{* *}$ & $9.41 \pm 1.30 *$ & $21.53 \pm 4.52$ \\
\hline Esterified cholesterol & $9.38 \pm 3.34$ & $8.94 \pm 2.77$ & $7.47 \pm 2.62$ & $12.19 \pm 1.93$ \\
\hline
\end{tabular}

Here and in Table 2-3: *, **, ***-the differences are statistically significant compared to the control group $(P<0.05-0.001)$

Ta b le 2. Fractional composition of total lipids in liver, $\%, M \pm m, n=5$

\begin{tabular}{|c|c|c|c|c|}
\hline \multirow{2}{*}{ Class of lipids } & \multirow{2}{*}{ Control group } & \multicolumn{3}{|c|}{ Experimental group } \\
\hline & & $\mathrm{A}$ & $\mathrm{E}$ & $\mathrm{M}$ \\
\hline Phospholipids & $22.89 \pm 2.19$ & $33.70 \pm 8.31$ & $43.27 \pm 10.03$ & $50.88 \pm 3.66^{* * *}$ \\
\hline Nonesterified cholesterol & $11.92 \pm 2.29$ & $9.85 \pm 1.31$ & $10.38 \pm 1.70$ & $6.13 \pm 1.11$ \\
\hline Mono- and diglycerides & $15.90 \pm 1.10$ & $12.16 \pm 0.53^{*}$ & $12.26 \pm 0.44^{*}$ & $10.12 \pm 1.61^{*}$ \\
\hline Free fatty acids & $15.79 \pm 1.21$ & $10.60 \pm 1.11^{*}$ & $7.96 \pm 1.48^{* *}$ & $6.92 \pm 0.74 * * *$ \\
\hline Triglycerides & $16.46 \pm 1.26$ & $14.89 \pm 4.92$ & $11.75 \pm 1.23^{*}$ & $10.85 \pm 0.78^{* *}$ \\
\hline Esterified cholesterol & $17.05 \pm 0.90$ & $18.80 \pm 1.60$ & $14.38 \pm 3.55$ & $15.11 \pm 1.06$ \\
\hline
\end{tabular}

Ta b le 3. Fractional composition of total lipids in the kidney, $\%, M \pm m, n=5$

\begin{tabular}{l|l|lll}
\hline \multirow{2}{*}{\multicolumn{1}{c}{ Class of lipids }} & \multirow{2}{*}{ Control group } & \multicolumn{3}{|c}{ Experimental group } \\
\cline { 3 - 5 } & & \multicolumn{1}{|c}{$\mathrm{A}$} & \multicolumn{1}{c}{$\mathrm{E}$} & $\mathrm{M}$ \\
\hline Phospholipids & $40.52 \pm 1.19$ & $49.64 \pm 8.41$ & $47.40 \pm 5.96$ & $41.61 \pm 6.31$ \\
Nonesterified cholesterol & $8.66 \pm 0.55$ & $8.66 \pm 1.14$ & $8.56 \pm 0.26$ & $11.68 \pm 1.03^{*}$ \\
Mono- and diglycerides & $11.71 \pm 1.98$ & $9.32 \pm 3.26$ & $9.40 \pm 1.03$ & $10.10 \pm 3.71$ \\
Free fatty acids & $6.55 \pm 0.36$ & $8.29 \pm 1.61$ & $8.63 \pm 2.49$ & $10.03 \pm 0.97^{* *}$ \\
Triglycerides & $16.76 \pm 0.99$ & $12.76 \pm 4.2$ & $11.57 \pm 1.17^{*}$ & $12.37 \pm 1.04^{*}$ \\
Esterified cholesterol & $15.80 \pm 0.88$ & $11.33 \pm 1.20^{*}$ & $14.44 \pm 3.06$ & $14.23 \pm 1.94$ \\
\hline
\end{tabular}

Thus, the observed redistribution of different fractions of total lipids in blood plasma, liver, and kidney in response to the administration of all thiosulfonates in rats are closely related to their involvement in the energy metabolism, in particular, the regulation of the activity of various enzymes included in lipid metabolism.

Intraperitoneal administration of thiosulfonates at a dose of $300 \mathrm{mg} / \mathrm{kg}$ of body weight did not significantly affect the content of total lipids and phospholipids in blood plasma, liver and kidney of rats, but led to the redistribution of their fractions. Methyl- and ethylthiosulfonates have a greater effect on the lipid metabolism in the liver, which is reflected in the decrease of the content of mono-, diand triglycerides and free fatty acids. Methyl- and ethylthiosulfonates also reduced the triglycerides content in the kidney. 


\section{ВПЛИВ ТІОСУЛЬФОНАТІВ НА ЛІПІДНИЙ СКЛАД ТКАНИН ЩУРІВ}

А. 3. Пилипець ${ }^{1,2}$, Р. Я. Іскра ${ }^{2}$,

В. В. Гавриляк ${ }^{1,2}$, А. В. Наконечна ${ }^{1}$, В. П. Новіков ${ }^{1}$ В. І. Лубенещь ${ }^{1 *}$

${ }^{1}$ Національний університет «Львівська політехніка», Україна;

${ }^{2}$ Інститут біології тварин НААН України, Львів; e-mail: vlubenets@gmail.com

Тіосульфонати - синтетичні аналоги органічних сульфурвмісних сполук, виділених iз рослин. Недавні дослідження показали, що ці сполуки ефективні у разі гіперліпідемії і здатні знижувати вміст холестеролу в організмі. Мета наших досліджень полягала у вивченні впливу синтезованих тіосульфонатів на вміст ліпідів та їхній склад у крові, печінці, нирках щурів. Вміст загальних ліпідів та співвідношення їх класів визначали методом тонкошарової хроматографії. Встановлено, що введення метил-, етил- та алілтіосульфонатів (300 мг/кг) не спричиняло істотних змін у вмісті загальних ліпідів та фосфоліпідів, проте призводило до перерозподілу їх класів у досліджуваних тканинах. За дії етил- та алілтіосульфонатів спостерігали зниження вмісту триацилгліцеролів у плазмі крові на 29,14 та $23,19 \%(P<0,05-0,01)$ відповідно, в той час як введення метил- та етилтіосульфонатів супроводжувалося вірогідним зменшенням моно-, ди-, триацилгліцеролів та вільних жирних кислот у тканині печінки порівняно 3 контролем. Найістотніші зміни ліпідного спектра тканини нирок виявлені за дії метилтіосульфонату.

К л ю ч о в і с лов в: тіосульфонати, кров, печінка, нирки, загальні ліпіди, фосфоліпіди, фракційний склад.

\section{ВЛИЯНИЕ ТИОСУЛЬФОНАТОВ НА ЛИПИДНЫЙ СОСТАВ ТКАНЕЙ КРЫС}

А. 3. Пилипеи ${ }^{1,2}$, Р. Я. Искра ${ }^{2}$,

В. В. Гавриляк ${ }^{1,2}$, А. В. Наконечна ${ }^{1}$, В. П. Новиков ${ }^{1}$ В. И. Лубенеи ${ }^{1}$

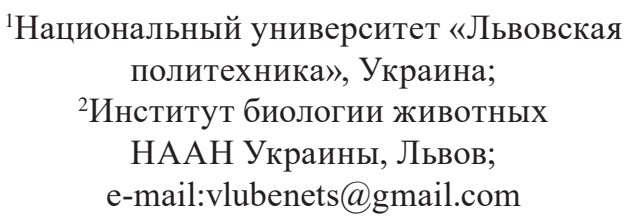

Тиосульфонаты - синтетические аналоги органических серосодержащих соединений, выделенных из растений. Недавние исследования показали, что эти соединения эффективны при гиперлипидемии и способны снижать содержание холестерола в организме. Цель наших исследований заключалась в изучении влияния синтезированных тиосульфонатов на содержание липидов и их состав в крови, печени и почках крыс. Содержание общих липидов и соотношение их классов определяли методом тонкослойной хроматографии. Установлено, что введение метил-, этил- и аллилтиосульфонатов (300 мг/кг) не вызывало существенных изменений в содержании общих липидов и фосфолипидов, однако приводило к перераспределению их классов в исследуемых тканях. Под воздействием этил- и аллилтиосульфонатов содержание триацилглицеролов в плазме крови снижалось на 29,14 и $23,19 \%(P<0,05-0,01)$ соответственно, в то время как введение метил- и этилтиосульфонатов сопровождалось достоверным уменьшением моно-, ди-, триацилглицеролов и свободных жирных кислот в ткани печени по сравнению с контролем. Существенные изменения липидного состава ткани почек наблюдались под воздействием метилтиосульфоната.

К л ю ч е вы е с л о в а: тиосульфонаты, кровь, печень, почки, общие липиды, фосфолипиды, фракционный состав. 


\section{References}

1. Iciek M, Kwiecień I, Włodek L. Biological properties of garlic and garlic-derived organosulfur compounds. Environ Mol Mutagen. 2009; 50(3): 247-265.

2. Lubenets VI. Thiosulphonates: synthesis and properties. Ukr Khim Zhurn. 2003; 69(3): 109117.

3. Boldyrev BH, Bylozor TK, Vlyzlo RY, Lubenets VY, Kozharskiy AI, Luzhetskaya OV, Spas LE, Solonin VN. Anrimicrobial and physiological activities of thiosulfoesthers possible ways of practical use in various areas of the national economy. Biodeterioration in industry. 1983; Gorkiy, GSU. 44-52. (In Russian).

4. Lubenets V, Karpenko O, Ponomarenko M, Zahoriy G, Krychkovska A, Novikov V. Development of new antimicrobial compositions of thiosulfonate structure. Chem Chem Technol. 2013; 7(2): 119-124.

5. Peinado MJ, Ruiz R, Echávarri A, Rubio LA. Garlic derivative propyl propane thiosulfonate is effective against broiler enteropathogens in vivo. Poult Sci. 2012; 91(9): 2148-2157.

6. Zheng Y, Qing FL, Huang Y, Xu XH. Tunable and practical synthesis of thiosulfonates and disulfides from sulfonyl chlorides in the presence of tetrabutylammonium iodide. Adv Synth Catal. 2016; 358(21): 3477-3481.

7. Kim DK, Lillehoj HS, Lee SH, Lillehoj EP, Bravo D. Improved resistance to Eimeria acervulina infection in chickens due to dietary supplementation with garlic metabolites. $\mathrm{Br} J$ Nutr. 2013; 109(1): 76-88.

8. Abad P, Lara FJ, Arroyo-Manzanares N, Baños A, Guillamón E, García-Campaña AM. High-performance liquid chromatography method for the monitoring of the allium derivative propyl propane thiosulfonate used as natural additive in animal feed. Food Anal Methods. 2015; 8(4): 916-921.

9. Abad P, Arroyo-Manzanares N, Gil L, GarcíaCampaña AM. Use of onion extract as a dairy cattle feed supplement: monitoring propyl propane thiosulfonate as a marker of its effect on milk attributes. J Agric Food Chem. 2017; 65(4):7 93-799.

10. Zenkov NK, Menshchikova EB, Kandalintseva NV, Oleynik AS, Prosenko AE, Gusachenko ON, Shklyaeva OA, Vavi- lin VA, Lyakhovich VV. Antioxidant and antiinflammatory activity of new watersoluble sulfur-containing phenolic compounds. Biochemistry (Mosc). 2007; 72(6): 644-651.

11. Herman-Antosiewicz A, Powolny AA, Singh SV. Molecular targets of cancer chemoprevention by garlic-derived organosulfides. Acta Pharmacol Sin. 2007; 28(9): 1355-1364.

12. Dirsch VM, Gerbes AL, Vollmar AM. Ajoene, a compound of garlic, induces apoptosis in human promyeloleukemic cells, accompanied by generation of reactive oxygen species and activation of nuclear factor kappaB. Mol Pharmacol. 1998; 53(3): 402-407.

13. Das A, Banik NL, Ray SK. Garlic compounds generate reactive oxygen species leading to activation of stress kinases and cysteine proteases for apoptosis in human glioblastoma T98G and U87MG cells. Cancer. 2007; 110(5): 1083-1095.

14. Pagliei B, Aquilano K, Baldelli S, Ciriolo MR. Garlic-derived diallyl disulfide modulates peroxisome proliferator activated receptor gamma co-activator 1 alpha in neuroblastoma cells. Biochem Pharmacol. 2013; 85(3): 335-344.

15. Kelkel M, Cerella C, Mack F, Schneider T, Jacob C, Schumacher M, Dicato M, Diederich M. ROS-independent JNK activation and multisite phosphorylation of Bcl-2 link diallyl tetrasulfide-induced mitotic arrest to apoptosis. Carcinogenesis. 2012; 33(11): 2162-2171.

16. Lubenets VI, Parashchyn ZhD, Vasylyuk SV, Novikov VP. TheS-Methyl-(2-Methoxycarbonylamino-Benzimidazole-5) Thiosulfonate as Potential Anticancer Agents. Glob J Pharmaceu Sci. 2017; 3(2): 555-607.

17. Lubenets V, Vasylyuk S, Monka N, Bolibrukh K, Komarovska-Porokhnyavets O, Baranovych D, Musyanovych R, Zaczynska E, Czarny A, Nawrot U, Novikov V. Synthesis and antimicrobial properties of 4-acylaminobenzenethiosulfoacid S-esters. Saudi Pharm J. 2017; 25(2): 266-274.

18. Folch J, Lees M, Sloane Stanley GH. A simple method for the isolation and purification of total lipides from animal tissues. J Biol Chem. 1957; 226(1): 497-509.

19. Kates M. Techniques of lipidology. Isolation, analysis and identification of lipids. Amsterdam: Elsevier, 1986. 464 p. 
20. Liu L, Yeh YY. Inhibition of cholesterol biosynthesis by organosulfur compounds derived from garlic. Lipids. 2000; 35(2): 197-203.

21. Kreps EM. Cell Membrane Lipids. Nauka Publ., 1981. 339 p. (In Russian).

22. Rabinkov A, Miron T, Mirelman D, Wilchek M, Glozman S, Yavin E, Weiner L. S-Allylmercaptoglutathione: the reaction product of allicin with glutathione possesses $\mathrm{SH}$ modifying and antioxidant properties. Biochim Biophys Acta. 2000; 1499(1-2): 144-153.
23. Yeh YY, Liu L. Cholesterol-lowering effect of garlic extracts and organosulfur compounds: human and animal studies. J Nutr. 2001; 131(3s): 989S-993S.

24. Gula NM, Margitich VM. Fatty acids and their derivates in pathological states. Kyiv: Naukova dumka, 2009. 335 p. (In Ukrainian).

25. Gulik-Krzywicki T. Structural studies of the associations between biological membrane components. Comp Biochem Physiol. 1995; 105(1): 161-214.

Received 25.09.2017 